\title{
Metrological framework to support accurate, reliable, and reproducible nucleic acid measurements
}

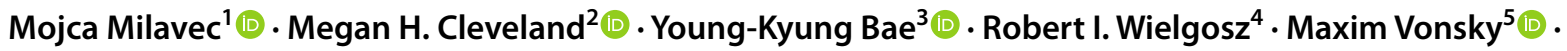 \\ Jim F. Huggett ${ }^{6,7}$ (D)
}

Received: 4 July 2021 / Revised: 5 September 2021 / Accepted: 1 October 2021 / Published online: 4 November 2021

(c) The Author(s) 2021

\begin{abstract}
Nucleic acid analysis is used in many areas of life sciences such as medicine, food safety, and environmental monitoring. Accurate, reliable measurements of nucleic acids are crucial for maximum impact, yet users are often unaware of the global metrological infrastructure that exists to support these measurements. In this work, we describe international efforts to improve nucleic acid analysis, with a focus on the Nucleic Acid Analysis Working Group (NAWG) of the Consultative Committee for Amount of Substance: Metrology in Chemistry and Biology (CCQM). The NAWG is an international group dedicated to improving the global comparability of nucleic acid measurements; its primary focus is to support the development and maintenance of measurement capabilities and the dissemination of measurement services from its members: the National Metrology Institutes (NMIs) and Designated Institutes (DIs). These NMIs and DIs provide DNA and RNA measurement services developed in response to the needs of their stakeholders. The NAWG members have conducted cutting edge work over the last 20 years, demonstrating the ability to support the reliability, comparability, and traceability of nucleic acid measurement results in a variety of sectors.
\end{abstract}

Keywords Nucleic acids (DNA I RNA) · Measurements · Accuracy $\cdot$ Traceability

\section{Introduction}

Published in the topical collection Recent Trends in (Bio)-Analytical Chemistry with guest editors Antje J. Baeumner and Günter Gauglitz.

Mojca Milavec

mojca.milavec@nib.si

1 Department of Biotechnology and Systems Biology, National Institute of Biology, Večna pot 111, 1000 Ljubljana, Slovenia

2 National Institute of Standards and Technology, 100 Bureau Drive, Gaithersburg, MD 20899, USA

3 Korea Research Institute of Standards and Science (KRISS), Daejeon, Republic of Korea

4 Bureau International Des Poids Et Mesures (BIPM), Pavillon de Breteuil, 92312 Sèvres Cedex, France

5 D.I. Mendeleev Institute for Metrology, Moskovsky pr., 19, Saint-Petersburg 190005, Russian Federation

6 National Measurement Laboratory (NML), LGC, Queens Road, Teddington TW11 0LY, Middlesex, UK

7 School of Biosciences \& Medicine, Faculty of Health \& Medical Science, University of Surrey, Guildford, UK
Nucleic acid (NA) analysis is fundamental for many areas of life sciences including biotechnology, cell biology, genetics, microbiology, and molecular biology. Applied nucleic acid analysis is increasingly required for applications in different fields such as medicine, pharmacy, veterinary medicine, food safety, and environmental monitoring. Nucleic acid analysis encompasses the detection, identification, and quantification of nucleic acids from different organisms, often from diverse matrices. Accurate and metrologically traceable measurements of nucleic acids enable reliable results to support decision makers like healthcare workers, sanitary inspectors, and competent authorities.

In the last few decades, nucleic acid analysis has rapidly developed supported by an increasingly diverse array of technologies. After the understandable slow beginnings of RNA sequencing in the 1960s, DNA sequencing in the 1970s, and the invention of polymerase chain reaction (PCR) in the 1960s, all these analytical approaches faced extremely intensive developments. Currently, RNA sequencing is an indispensable tool for transcriptome-wide analysis and 
is contributing to a fuller understanding of RNA biology [1]; third-generation DNA sequencing has revolutionized sequencing by increasing the length of reads and reducing the time and costs of analysis [2, 3]; and digital PCR (dPCR) has enabled absolute quantification of specific nucleic acid targets [4].

Despite broad use of nucleic analysis, comparability of nucleic acid quantification results is unsatisfactory among laboratories in many areas. This is especially evident where quantitative analysis of nucleic acids is required. For example, in the food and feed safety area, national reference laboratories and official control laboratories in the European Union use common validated methods to determine the mass fraction of the genetically modified organisms (GMOs) in samples. Reports on laboratory performances in the proficiency tests provided by the European Union Reference Laboratory for Genetically Modified Food and Feed (EURLGMFF) [5] usually show up to fivefold and occasionally up to tenfold differences among laboratory results $[6,7]$. Additionally, in External Quality Assessment schemes, results from participating laboratories can vary by more than 100 fold $[8,9]$.

It is unfortunate that metrology, the science of measurement, and metrological considerations (such as routes to traceability and sources of uncertainty) are sometimes overlooked in a number of applied areas, with those applying nucleic acid analysis typically assuming their systems are fit for purpose in this respect. Certainly, many breakthroughs in sequence discovery, genome evaluation, and routine monitoring have succeeded without the assistance of the measurement science community. Yet as these fields have pushed to offer ever more high-throughput ("omics") and precise quantitative solutions, they have been met with challenges associated with standardization and traceability of measurement results. Many of those working in these spaces neither realize that measurement science is a field in its own right, nor that a global infrastructure exists to support them in this respect. Given the wide variety of applications in the nucleic acid analysis space, there are numerous examples where applying measurement science could support improving the routine application both in basic research and applied scenarios. This overview outlines the benefits of metrological support for nucleic acid analysis in the life science sectors that are more metrologically established, while also championing advancements in the other sectors.

\section{NAWG at CCQM}

Many international organizations and societies are making efforts to improve the consistency of results among laboratories in general such as the International Organization for Standardization (ISO) [10] or the European Committee for Standardization (Cen) [11] and in specific fields like healthcare, e.g., the World Health Organization (WHO) [12], the Joint Committee for Traceability in Laboratory Medicine (JCTLM) [13], the International Federation of Clinical Chemistry and Laboratory Medicine (IFCC) [14], the Standardisation of Genome Amplification Techniques (SoGAT) [15], and the European Society of Clinical Microbiology and Infectious Diseases (ESCMID) [16]; or food safety and security in the field of detection, identification, and quantification of genetically modified organisms, e.g., the European Network of GMO Laboratories (ENGL) [17] and the Codex Alimentarius [18]; or in plant health, e.g., the International Plant Protection Convention (ICPP) [19] and the European and Mediterranean Plant Protection Organization (EPPO) [20]. Short descriptions of listed organizations, bodies, and societies are in Table 1.

One of the international groups dedicated to improving the comparability of nucleic acid measurements independent of the field is the Working Group on Nucleic Acid Analysis (NAWG) [37] of the Consultative Committee for Amount of Substance: Metrology in Chemistry and Biology (CCQM) [25]. CCQM is one of the consultative committees (CCs) of the International Committee for Weights and Measures (CIPM) [27] with a mission to advance global comparability of chemical and biological measurement standards and capabilities, enabling member states and associates to make measurements with confidence, and with a published strategy for 2021-2030 [43] to do so. Among its activities, CCQM has responsibility for developing, improving, and documenting the equivalence of National Metrological Institutes (NMIs) and Designated Institutes (DIs) calibration and measurement capabilities, national standards (certified reference materials and reference methods) for chemical and biological measurements, following the processes set out in the CIPM Mutual Recognition Arrangement (CIPM MRA) [28]. More information on the bodies mentioned above is in Table 1.

Activities related to nucleic acid analysis within CCQM began in 1999, the year that the XXI General Conference for Weights and Measures (CGPM) [26] discussed the growing importance of biotechnology in human health, food production, forensic medicine, and the protection of the environment. CCQM recognized the need for accurate, SI-traceable measurements in these fields and the lack of an adequate metrological infrastructure to ensure such traceability. It recommended that national laboratories consider developing programs related to the measurement of quantities important in biotechnology and that national laboratories collaborate with international scientific unions and organizations to establish an adequate international measurement infrastructure to ensure traceability to the SI in measurements in biotechnology. 
Table 1 List of abbreviations and short descriptions of relevant metrology and standardization/harmonization bodies, associations, organizations, consortia, and programs

\begin{tabular}{|c|c|c|}
\hline Abbreviation & Short description & Reference \\
\hline \multicolumn{3}{|c|}{ Metrology bodies, organizations, consortia, and programs } \\
\hline APMP & $\begin{array}{l}\text { Asia Pacific Metrology Programme is a group of NMIs from the Asia-Pacific region engaged in } \\
\text { improving regional metrological capability through the sharing of expertise and exchange of technical } \\
\text { services among member laboratories. APMP is also a RMO recognized by the CIPM for the purpose of } \\
\text { worldwide mutual recognition of measurement standards and of calibration and measurement certifi- } \\
\text { cates }\end{array}$ & {$[21]$} \\
\hline BAWG & $\begin{array}{l}\text { BioAnalysis Working Group was established in } 2001 \text { and dedicated to the emerging field of metrol- } \\
\text { ogy in biology. Due to the increasing and more specialized activities, BAWG was split into three new } \\
\text { CCQM working groups: CAWG, NAWG, and PAWG }\end{array}$ & {$[22]$} \\
\hline BIPM & $\begin{array}{l}\text { International Bureau of Weights and Measures (French: Bureau International des Poids et } \\
\text { Mesures) is the intergovernmental organization in which governments cooperate on matters of metrol- } \\
\text { ogy and measurement standards }\end{array}$ & {$[23]$} \\
\hline CAWG & $\begin{array}{l}\text { Cell Analysis Working Group of the CCQM is an international group dedicated to improving the global } \\
\text { comparability of cell measurements, including identification and quantification of intact cells and cell } \\
\text { properties indicative of function in complex matrices and mixtures }\end{array}$ & {$[24]$} \\
\hline CCQM & $\begin{array}{l}\text { Consultative Committee for Amount of Substance: Metrology in Chemistry and Biology is respon- } \\
\text { sible for developing, improving, and documenting the equivalence of national standards (certified refer- } \\
\text { ence materials and reference methods) for chemical and biological measurements. It advises the CIPM } \\
\text { on matters related to chemical and biological measurements, including advice on the BIPM scientific } \\
\text { program activities }\end{array}$ & {$[25]$} \\
\hline CGPM & $\begin{array}{l}\text { General Conference for Weights and Measures is the supreme body of BIPM. The CGPM is composed } \\
\text { of delegates of the governments of the member states and observers from the associates of the CGPM. } \\
\text { Under its authority, the CIPM exercises exclusive direction and supervision of the BIPM }\end{array}$ & {$[26]$} \\
\hline CIPM & $\begin{array}{l}\text { International Committee for Weights and Measures is promoting worldwide uniformity in units of } \\
\text { measurement and does so through direct action or by submitting draft resolutions to the CGPM }\end{array}$ & {$[27]$} \\
\hline CIPM MRA & $\begin{array}{l}\text { CIPM Mutual Recognition Arrangement is the framework through which NMIs demonstrate the inter- } \\
\text { national equivalence of their measurement standards and the calibration and measurement certificates } \\
\text { they issue }\end{array}$ & {$[28]$} \\
\hline $\mathrm{CMC}$ & $\begin{array}{l}\text { Under a Calibration and Measurement Capability, the measurement or calibration should be (a) } \\
\text { performed according to a documented procedure and have an established uncertainty budget under the } \\
\text { management system of the institute; (b) performed on a regular basis (including on demand or sched- } \\
\text { uled for convenience at specific times in the year); and (c) available to all customers }\end{array}$ & {$[29]$} \\
\hline COOMET & $\begin{array}{l}\text { Euro-Asian Cooperation of National Metrological Institutions is a joint forum of metrologists of the } \\
\text { Euro-Asian region, a steadily and effectively working regional metrology organization. Cooperation } \\
\text { within COOMET and its results allow its member countries to successfully solve metrological issues, } \\
\text { which national economies face under the conditions of market globalization }\end{array}$ & {$[30]$} \\
\hline DI & $\begin{array}{l}\text { Designated Institute is operating at the top of the national metrology system like NMI, complementing } \\
\text { the fields of activities of the NMI and bringing in expertise in metrological areas not covered by the } \\
\text { NMI }\end{array}$ & I \\
\hline EMRP & $\begin{array}{l}\text { European Metrology Research Programme (2009-2013) has enabled European metrology institutes, } \\
\text { industrial organizations, and academia to collaborate on joint research projects within specified fields: } \\
\text { industry, energy, environment, health, new technologies, and SI units }\end{array}$ & {$[31]$} \\
\hline EMPIR & $\begin{array}{l}\text { European Metrology Programme for Innovation and Research (2014-2020) coordinated research } \\
\text { projects to address grand challenges, while supporting and developing the SI system of units of meas- } \\
\text { urement. There was an increased focus on innovation activities to address industry needs and accelerate } \\
\text { the uptake of research outputs. The capacity-building projects of the program aimed at bridging the } \\
\text { gap between EU member states with emerging measurement systems and those with more developed } \\
\text { capabilities }\end{array}$ & {$[32]$} \\
\hline ERCC & $\begin{array}{l}\text { The aim of the External RNA Controls Consortium is to build the measurement assurance tools needed } \\
\text { to support reproducible gene expression measurements. ERCC partners from industry, government, and } \\
\text { academia develop RNA spike-in controls and establish analytical methods for bringing reproducible } \\
\text { gene expression measurements into routine, high-quality practice }\end{array}$ & {$[33]$} \\
\hline EURAMET & $\begin{array}{l}\text { European Association of National Metrology Institutes is the RMO of Europe. EURAMET coor- } \\
\text { dinates the cooperation of NMIs in Europe in fields such as research in metrology, traceability of } \\
\text { measurements to the SI units, international recognition of national measurement standards, and related } \\
\text { CMCs. Through knowledge transfer and cooperation among the members, EURAMET facilitates the } \\
\text { development of the national metrology infrastructures }\end{array}$ & {$[34]$} \\
\hline
\end{tabular}


Table 1 (continued)

\begin{tabular}{|c|c|c|}
\hline Abbreviation & Short description & Reference \\
\hline $\mathrm{KCDB}$ & $\begin{array}{l}\text { Key Comparisons Database is a freely available web resource related to the CIPM MRA. The outputs of } \\
\text { CIPM MRA are the internationally recognized (peer-reviewed and approved) CMCs of the participating } \\
\text { institutes. Approved CMCs and supporting technical data are publicly available from the KCDB }\end{array}$ & {$[35]$} \\
\hline MWG 8 & $\begin{array}{l}\text { Chemical Metrology Working Group in SIM supports SIM and its member NMIs/DIs in reaching the } \\
\text { obligations and requirements of CIPM-MRA in the field of metrology in chemistry and biology meas- } \\
\text { urements }\end{array}$ & {$[36]$} \\
\hline NAWG & $\begin{array}{l}\text { Nucleic Acid Analysis Working Group of the CCQM is an international group dedicated to improving } \\
\text { the global comparability and metrological traceability of measurement results for the analysis of nucleic } \\
\text { acid polymer sequences, their modifications, and their abundance }\end{array}$ & {$[37]$} \\
\hline NMI & $\begin{array}{l}\text { National Metrology Institute is the national authority on measurement. National metrology institutes } \\
\text { have the responsibility of maintaining national measurement standards and disseminating the interna- } \\
\text { tional system of units nationally }\end{array}$ & / \\
\hline PAWG & $\begin{array}{l}\text { Protein Analysis Working Group of the CCQM is an international group dedicated to improving the } \\
\text { global comparability of protein measurements, including (a) development and validation of reference } \\
\text { measurement procedures for purity assessment of high-purity peptide and protein materials suitable } \\
\text { for calibration standards and (certified) reference materials; (b) qualitative and quantitative analyses of } \\
\text { peptides and proteins in complex biological matrices and biopharmaceuticals; (c) other more specialized } \\
\text { measurements related to proteins such as catalytic enzymatic activities, as well as biotherapeutic and } \\
\text { antibody characterization }\end{array}$ & {$[38]$} \\
\hline RMO & $\begin{array}{l}\text { Regional metrology organizations are regional associations of national metrology institutes. They play } \\
\text { an important role in the CIPM MRA as they (a) make proposals to the consultative committees on the } \\
\text { choice of key comparisons, (b) carry out the RMO key comparisons, described in the Technical Sup- } \\
\text { plement to the CIPM MRA, corresponding to the CIPM key comparisons; (c) participate in the joint } \\
\text { committee of the regional metrology organizations and the BIPM; and (d) carry out supplementary } \\
\text { comparisons and other actions designed to support mutual confidence in the validity of calibration and } \\
\text { measurement certificates issued by participating institutes }\end{array}$ & / \\
\hline SI & International System of Units is the recommended practical system of units of measurement & {$[39,40]$} \\
\hline SIM & $\begin{array}{l}\text { Inter-American Metrology System was created to promote international, and regional, and particularly } \\
\text { Inter-American cooperation in metrology issues and is committed to implementing a global measuring } \\
\text { system upon which all users may rely. SIM promotes and supports an integrated measurement infra- } \\
\text { structure in the Americas, which enables each member NMI to stimulate innovation, competitiveness, } \\
\text { trade, consumer safety, and sustainable development by effectively participating in the international } \\
\text { metrology community }\end{array}$ & {$[41]$} \\
\hline $\mathrm{TC}-\mathrm{MC}$ & $\begin{array}{l}\text { Technical Committee of Metrology in Chemistry is a Joint EURAMET-Eurachem Technical Com- } \\
\text { mittee. It is concerned with primary methods and reference materials for chemical measurements and } \\
\text { research in metrology to support different sectors in chemistry. Nucleic acid analysis activities are under } \\
\text { the responsibility of the SubCommittee Bio and Organic Analysis }\end{array}$ & {$[42]$} \\
\hline TCQM & $\begin{array}{l}\text { Technical Committee Amount of Substance of APMP is responsible for developing and improving the } \\
\text { equivalence of national reference systems for chemical and biological measurements. The TCQM is also } \\
\text { responsible for initiating and monitoring the TCQM comparison programs and ensuring that these link } \\
\text { to the international comparison programs conducted through the CIPM CCQM }\end{array}$ & {$[21]$} \\
\hline \multicolumn{3}{|c|}{ Standardization/harmonization bodies and organizations } \\
\hline Cen & $\begin{array}{l}\text { European Committee for Standardization is an association that brings together the National Standardi- } \\
\text { zation Bodies of } 34 \text { European countries }\end{array}$ & {$[11]$} \\
\hline Codex Alimentarius & $\begin{array}{l}\text { The Codex Alimentarius is a collection of internationally adopted food standards and related texts pre- } \\
\text { sented in a uniform manner. These food standards and related texts aim at protecting consumers' health } \\
\text { and ensuring fair practices in the food trade. The publication of the Codex Alimentarius is intended to } \\
\text { guide and promote the elaboration and establishment of definitions and requirements for foods to assist } \\
\text { in their harmonization and in doing so to facilitate international trade }\end{array}$ & {$[18]$} \\
\hline ESCMID & $\begin{array}{l}\text { European Society of Clinical Microbiology and Infectious Diseases is a non-profit organization whose } \\
\text { mission is to improve the diagnosis, treatment, and prevention of infection-related diseases. This is } \\
\text { achieved by promoting and supporting research, education, training, and good medical practice }\end{array}$ & {$[16]$} \\
\hline EURL-GMFF & $\begin{array}{l}\text { European Union Reference Laboratory for Genetically Modified Food and Feed is responsible for } \\
\text { the scientific assessment and validation of detection methods for genetically modified food and feed as } \\
\text { part of the European Union authorization procedure and provides support to the National Reference } \\
\text { Laboratories for control of GMOs in the European Union member states }\end{array}$ & {$[5]$} \\
\hline
\end{tabular}


Table 1 (continued)

\begin{tabular}{|c|c|c|}
\hline Abbreviation & Short description & Reference \\
\hline ENGL & $\begin{array}{l}\text { European Network of GMO Laboratories plays an eminent role in the development, harmonization, } \\
\text { and standardization of means and methods for sampling, detection, identification, and quantification of } \\
\text { genetically modified organisms (GMOs) in a wide variety of products, ranging from seeds, grains, to } \\
\text { food and feed stuff }\end{array}$ & {$[17]$} \\
\hline EPPO & $\begin{array}{l}\text { European and Mediterranean Plant Protection Organization is an intergovernmental organization } \\
\text { responsible for cooperation in plant health within the Euro-Mediterranean region. Its objectives are to } \\
\text { protect plants, by developing international strategies against the introduction and spread of pests which } \\
\text { are a threat to agriculture, forestry, and the environment, and by promoting safe and effective pest con- } \\
\text { trol methods. EPPO is a standard-setting organization which has produced a large number of standards } \\
\text { in the areas of plant protection products and plant quarantine }\end{array}$ & {$[20]$} \\
\hline ICPP & $\begin{array}{l}\text { International Plant Protection Convention is an intergovernmental treaty signed by over } 180 \text { countries, } \\
\text { aiming to protect the world's plant resources from the spread and introduction of pests, and promoting } \\
\text { safe trade. The convention introduced international standards for phytosanitary measures as its main tool } \\
\text { to achieve its goals, making it the sole global standard setting organization for plant health }\end{array}$ & [19] \\
\hline IFCC & $\begin{array}{l}\text { International Federation of Clinical Chemistry and Laboratory Medicine is a worldwide, non- } \\
\text { political organization for clinical chemistry and laboratory medicine. As such, it has a range of roles that } \\
\text { include (1) global standard setting in collaboration with other international organizations, (2) supporting } \\
\text { its members through scientific and educational endeavor, and (3) providing a series of congresses, con- } \\
\text { ferences and focused meetings in order for laboratory medicine specialists to meet and present original } \\
\text { findings and best practice }\end{array}$ & [14] \\
\hline ISO & $\begin{array}{l}\text { International Organization for Standardization is an independent, non-governmental international } \\
\text { organization developing and publishing international standards }\end{array}$ & {$[10]$} \\
\hline JCTLM & $\begin{array}{l}\text { Joint Committee for Traceability in Laboratory Medicine is an international consortium that promotes } \\
\text { the global standardization of clinical laboratory test results, and provides information on reference mate- } \\
\text { rials, reference measurement methods, and services that are available from around the world }\end{array}$ & [13] \\
\hline SoGAT & $\begin{array}{l}\text { Standardisation of Genome Amplification Techniques is an international working group dedicated to } \\
\text { the standardization of nucleic acid amplification technology-based tests for human infectious diseases }\end{array}$ & {$[15]$} \\
\hline WHO & $\begin{array}{l}\text { World Health Organization is the United Nations agency that connects nations, partners, and people } \\
\text { to promote health. WHO is dedicated to the well-being of all people and guided by science leads and } \\
\text { champions global efforts to give everyone, everywhere an equal chance to live a healthy life }\end{array}$ & [12] \\
\hline \multicolumn{3}{|c|}{ Other relevant abbreviations } \\
\hline CRM & $\begin{array}{l}\text { Certified reference material is reference material, accompanied by documentation issued by an authori- } \\
\text { tative body and providing one or more specified property values with associated uncertainties and trace- } \\
\text { abilities, using valid procedures }\end{array}$ & {$[40]$} \\
\hline dPCR & $\begin{array}{l}\text { Digital polymerase chain reaction is advanced PCR enabling quantification of a specific region of a } \\
\text { nucleic acid }\end{array}$ & \\
\hline GMOs & $\begin{array}{l}\text { Genetically modified organisms are animals, plants, or microbes whose genetic material has been } \\
\text { changed using techniques of modern biotechnology called gene technology or genetic engineering }\end{array}$ & \\
\hline NIPT & Non-invasive prenatal testing & \\
\hline PCR & $\begin{array}{l}\text { Polymerase chain reaction is a common molecular biology technique used to produce multiple copies of } \\
\text { a specific region of DNA }\end{array}$ & \\
\hline $\mathrm{RM}$ & $\begin{array}{l}\text { Reference material is a material sufficiently homogeneous and stable with reference to specified proper- } \\
\text { ties, which has been established to be fit for its intended use in measurement or in examination of } \\
\text { nominal properties }\end{array}$ & {$[40]$} \\
\hline
\end{tabular}

An Ad Hoc Biometrology Task Group was established, and in 2000 , it presented a report on new measurement challenges. In 2001, this task group became the BioAnalysis Working Group (BAWG) of the CCQM [22]. In 2014, the BAWG was split into three new CCQM working groups according to major analytes: the Nucleic Acid WG - NAWG [37], the Protein Analysis WG - PAWG [38], and the Cell Analysis WG - CAWG [24] due to the growing number of separated activities and increased membership. In the same year, the name and the scope of the CCQM were broadened from CCQM-Metrology in Chemistry to CCQM-Metrology in Chemistry and Biology [25]. Short descriptions of working groups are in Table 1.

The focus of the NAWG is to support global comparability and metrological traceability of measurement results in the area of the analysis of nucleic acid polymer sequences, their modifications, and their abundance. Members of the NAWG are NMIs and DIs that provide nucleic acid measurement services developed in response to the needs of their national and international stakeholders. The ubiquity 
of the nucleic acid analysis methods, the molecules they target, and the associated challenges are agnostic to sectors in most cases. Consequently, as an international working group that focuses on nucleic acid analysis regardless of sector, the NAWG is uniquely placed to advance the measurements in one sector using knowledge from another [44]. This constitutes a firm basis for NAWG's ability to respond to challenges in the nucleic acid analysis field despite the field's rapid technological development and implementation. This was exemplified by the response of the NAWG to the COVID-19 pandemic through the SARS-CoV-2 pilot study (CCQM-P199.b) with the participation of 18 NMIs/DIs, many of whom had not previously measured viral genomic material [45]. The NAWG will need to explore how this pan sector characteristic can be capitalized on to support different groups of stakeholders in the future.

\section{Regional metrology organizations}

Regional metrology organizations (RMOs) also organize activities for metrology in nucleic acid analysis. In the Asia Pacific Metrology Programme (APMP) [21], the Technical Committee Amount of Substance (TCQM) is responsible for developing and improving the equivalence of national reference systems for chemical and biological measurements. While the activities of the TCQM involve quantification of microorganisms in drinking water and food, the quantification is currently not based on nucleic acid measurement but on classical microbiology and culture-based methods.

In the Euro-Asian Cooperation of National Metrological Institutions (COOMET) [30], the bioanalysis subcommittee was established under the Technical Committee 1.8 "PhysicChemistry" [46] in 2019 and the importance of genetic technologies and reference material development to ensure the traceability of bioanalytical measurements was noted. While a pilot interlaboratory comparison on quantitative determination of human DNA is ongoing, the first bioanalysis subcommittee meeting is expected to be held in 2021 and its activity will be aligned with the NAWG strategy.

Within the Inter-American Metrology System (SIM) [41], the field of metrology in chemistry and biology measurements is the responsibility of the Chemical Metrology Working Group 8 (MWG 8) [36]. MWG 8 provides tools to guarantee the traceability and reliability of measurement results from environmental monitoring to health care, including food quality and food safety. It also offers support in fundamental research ranging from material science (nanotechnology) to bioscience and biotechnology, fair trade, and innovation.

EURAMET is the European Association of National Metrology Institutes [34]. Nucleic acid analysis activities are the responsibility of the Technical Committee of Metrology in Chemistry (TC-MC), SubCommittee Bio and Organic Analysis [42]. In addition, European NMIs and DIs work closely together with stakeholders through the European Metrology Research Programme (EMRP) [31] and European Metrology Programme for Innovation and Research (EMPIR) [32]. Notable projects with relevance to nucleic acid analysis include "Metrology for monitoring infectious diseases, antimicrobial resistance, and harmful micro-organisms" (Infect-Met, HLT08) [47], "Novel materials and methods for the detection, traceable monitoring and evaluation of antimicrobial resistance" (AntiMicroresist, 15HLT07) [48], "Traceability for biologically relevant molecules and entities" (BioSITrace, SIB54) [49], and "Metrology to enable rapid and accurate clinical measurements in acute management of sepsis" (SEPTIMET, 18HLT03) [50]. Furthermore, the European Metrology Network for Traceability in Laboratory Medicine (EMN TraceLabmed) [51] brings stakeholders such as proficiency testing providers, in vitro diagnostics manufacturers, regulators, and NMIs/DIs together to address stakeholder needs, which is especially important in the light of the new European IVD regulation [52, 53].

\section{Standardization, traceability, and scientific challenges}

The primary focus of NAWG is to support the development and maintenance of measurement capabilities and dissemination of measurement services from NMIs/DIs. This is supported via interlaboratory studies to evaluate the competencies of NMIs and DIs and provide evidence of the validity and international equivalence of measurement services for customers and stakeholders worldwide. Based on their performance in the interlaboratory studies, NMIs and DIs can submit their calibration and measurement capabilities (CMCs) for review. Following the successful review by RMOs and designated CCQM members, CMCs are entered into the International Bureau of Weights and Measures (BIPM) [23] key comparison database (KCDB) $[29,35]$. CMCs are characterized by the measured quantity and associated measurement uncertainty (generally given at a 95\% level of confidence) for a given range, the method or instrument used, the values of influencing parameters, and any other relevant information [29]. In addition to supporting CMCs, NAWG is using these studies to underpin the development of reference measurement systems and to establish the traceability of measurements to the International System of Units [39].

In parallel with recognizing current and future needs in standardization and traceability, NAWG is also addressing some of the fundamental scientific challenges associated with nucleic acid analysis. Nucleic acids vary in their stability which can impact both reference materials and biobanks, 
as well as routine testing during sample handling, isolation, and purification. DNA is generally considered stable; however, low mass concentrations (less than $5 \mathrm{ng} / \mu \mathrm{L}$ ) of both DNA and RNA may require the addition of stabilizing "carrier" molecules (such as yeast tRNA or other background heterologous RNA/DNA) to prevent decreases in concentration over time. RNA can be less stable than DNA, both due to inherent chemical reasons and because RNases, which can quickly degrade RNA, can be both ubiquitous and stable in the environment. Reduced stability of an analyte (in reference materials or clinical samples) may impact the quantity of a given sequence or the composition of its matrix, both of which may affect the measurement result. Furthermore, information on the wider target sequence composition may also be useful as factors like fragment size may also affect stability, resulting in potential discrepancies between methods [54, 55].

Sequence, the order of nucleotide monomers in the polymeric nucleic acid single-strand or double-strand molecule, is a nominal property. Sequence value has no size or magnitude; it is established by what is called an examination procedure in metrology $[40,56]$. Sequences, obtained by nominal property value examinations, are deposited to genetic databases. The International Nucleotide Sequence Database Collaboration (INSDC) [57] was founded by GenBank [58], European Nucleotide Archive (ENA) [59], and DNA Databank of Japan (DDBJ) [60]. Since 2002, INSDC maintains the reference sequence database RefSeq [61], which includes the most well-characterized nucleotide and amino acid sequences, providing reference nominal property values for description of target sequences. While sequence examination offers different challenges in terms of standardization to quantitative measurement, there are ongoing activities where NMIs are supporting such approaches, such as in human genomics and metagenomics, as well as work highlighting sources of process error, such as bioinformatic pipelines. It is likely that metrology institutes and molecular reference laboratories will be able to support routine application of such approaches by better characterizing sources of sequence error.

Scientific challenges associated with the measurement of a given nucleic acid vary depending on the complexity of the nucleic acid in question (e.g., sequence, size, secondary structure, etc.) as well as the complexity of the matrix in which it has been presented, as nucleic acids are almost exclusively measured in solution. Consequently, considerations associated with sources of uncertainty and routes to traceability frequently include volume measurements as an additional factor. Nucleic acid analyses typically require multistep processes with prior manipulation of the sample to isolate and purify the nucleic acids for further analysis ("pre-analytical" steps). When conducting nucleic acid analysis, a key distinction is whether the analyte is a part of a larger molecule (typically the case with genes associated with genetic modification or pathogen genome) or whether it is contained within the sequence being measured (such as when measuring actionable cancer genetic variants or genetic polymorphism). From an analytical point of view, these two categories can present distinct challenges when considering sources of uncertainty. Furthermore, the analytical sources of error can differ when the same nucleic acid sequence is measured in different matrices (pure nucleic acids in aqueous solution, synthetic matrices, or biological samples) (Fig. 1a).

When discussing a particular measurement/examination, and associated challenges, the type of sample (including the properties of the nucleic acid and its matrix) must also be considered (Fig. 1a). At the simplest level of complexity, nucleic acids can vary from less than 100 to billions of bases (the term is used to describe a nucleotide monomer that is about $300 \mathrm{~g} / \mathrm{mol}$; consequently large DNA molecules can be $>10^{8} \mathrm{~g} / \mathrm{mol}$ ). Additionally, samples can consist of mixtures of different genomes, which further complicates measurement/examination. Further potential sources of error are added when additional steps are required to prepare nucleic acids for analysis, such as purification, nucleic acid digestion (e.g., restriction enzyme treatment), adaptation (e.g., adapter ligation), modification (bisulfite conversion), or reverse transcription (generation of complementary nucleic acids). Extraction (purification) is often required when performing nucleic acid analysis, because the matrix is typically unsuitable for the final molecular analysis steps. All these steps contribute to the uncertainty associated with the final analysis.

When considering a given analyte, the type of nucleic acid analysis (Fig. 1b) can be categorized into "targeted" methods (such as PCR or hybridization) or "non-targeted" methods (such as sequencing). Targeted methods identify defined sequence(s) (and potentially their quantities and/ or modifications), while with non-targeted methods, the nucleic acid sequence(s) (and potentially their quantities and/or modifications) is unknown and the analysis intends to determine this. The type of analysis can also be broadly categorized into presence/absence "nominal property" examination (e.g., sequence is present or not), measurements of relative quantity/fractional abundance (e.g., percentage of sequence), or absolute quantification (e.g., copy number of sequence per unit volume).

The NAWG has conducted leading work in nucleic acid analysis, demonstrating its ability to support the reliability, comparability, and traceability of nucleic acid measurement results. NAWG had dedicated extensive efforts to understanding and evaluating the absolute quantification of nucleic acid with digital PCR (dPCR). For example, NAWG has investigated the influence of the partition volume on the absolute quantification of DNA in terms of copy numbers 


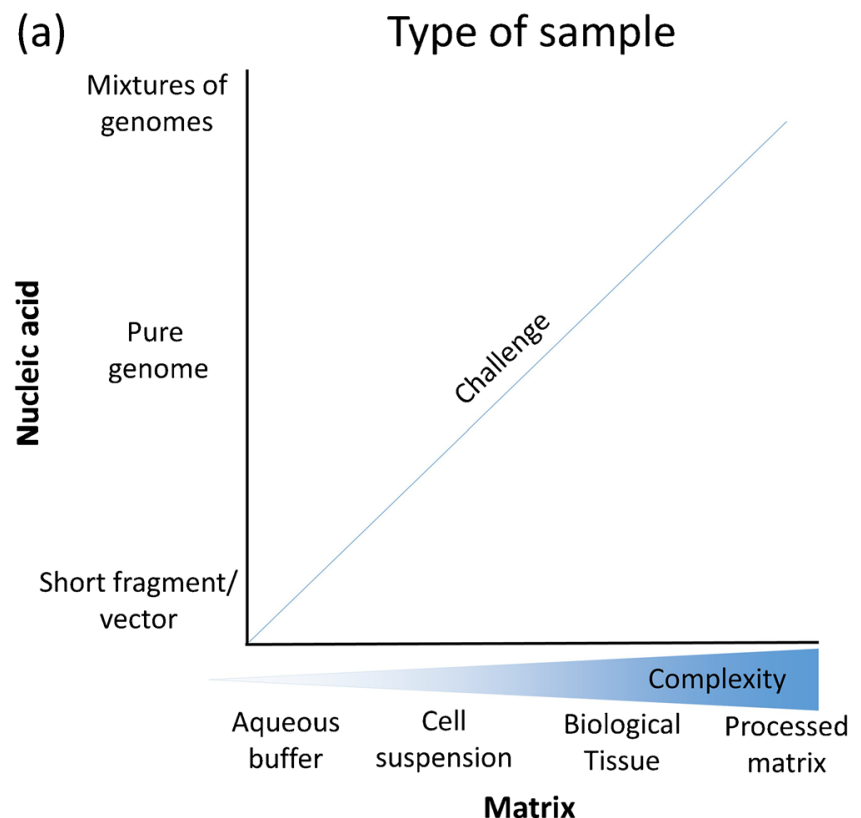

Fig. 1 Type of sample (a) and type of analysis (b); nucleic acid measurements/examinations vary in the complexity of the analysis and the type of sample. The simplest type of measurements would be the detection of the presence or absence of a plasmid in a buffered solu-

[62-65] and also demonstrated that the accuracy of dPCR measurement enables traceability to the International System of Units (SI) for copy number unit 1 through counting [66]. In addition, several members of NAWG were involved in the development of guidelines on APCR $[67,68]$ which aims to support researchers in standardizing their experimental protocols and reporting. Besides investigating and discussing the above-described common and general considerations in nucleic acid analysis, NAWG and its members are developing their measurement capacities in specific, stakeholderdriven fields like health and food safety.

Multiple NAWG members were involved in the development of guidelines on standardization for applying nucleic acid analysis. These guidelines give researchers advice on how to approach experimental design and how to report data to aid reproducibility [68-70]; many of these guidelines have been developed as part of wider activities to ensure transparency. In certain instances, these guidelines have contributed to the Minimum Information for Biological and Biomedical Investigations [71] which has, ironically, not typically included those from the NMI community. As food authenticity testing represents the most advanced example of the application of measurement science to nucleic acid analysis, there are numerous examples where associated guidance [72] and guidelines are available to support the most accurate application of molecular analysis [73-75]. As a result of the leading work that the NMIs have conducted over the last 20 years in nucleic acid analysis for foods, they are also

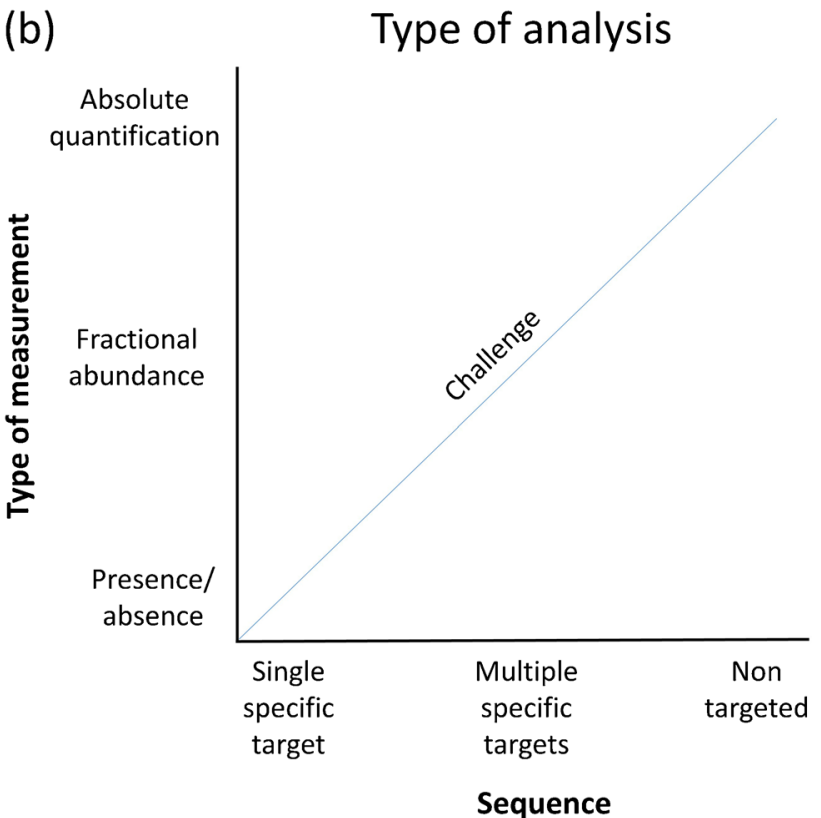

tion. A much more complex measurement would be the identification of all nucleic acid species in a processed food matrix, along with the abundance of each

increasingly supporting standards in other areas of molecular analysis such as biotechnology [76] and diagnostics [77]; nucleic acid analysis is also being included in standards for metrological traceability of in vitro diagnostic tests [78] due to work conducted by NAWG members. It is likely that the NAWG will continue to support an increasingly diverse range of stakeholders as the routine application of nucleic acid analysis increases.

\section{Metrology for food safety and authentication}

Nucleic acid analysis for food authentication is most metrologically advanced (in terms of traceability and understanding sources of uncertainty), relative to other routinely applied nucleic acid measurements. Therefore, most of the NAWG-supported CMCs for NMIs exist in the food analysis sector. To date (as of September 2021), all completed NAWG Key Comparisons have been in the area of food analysis and related to the needs of NMIs and DIs to provide services for detection, identification, and quantification of genetically modified organisms (GMOs) and food adulterations (Table S1).

The use of GMO crops has increased significantly since the 1990s. Commercial cultivation of GMOs contributes to global feed, fiber, food, and fuel production; however, the safety of GMOs and their products is a major concern in 
some countries. National legislation regulating GMOs and their products varies significantly across jurisdictions. A global reference measurement system, including reference materials and reference methods, needs to be established to facilitate international trade and provide consumers with information on the levels of GMO constituents. Nucleic acid analysis methods are commonly used to quantify GMO content in processed food and feed $[79,80]$ and to monitor for food adulteration [75].

NAWG is working to support members in developing nucleic acid reference materials and calibration services for relative GMO quantity and food adulteration. This process involves DNA extraction from a complex biological matrix, followed by measurement of specific genomic DNA fragments-the GMO-specific sequence and the endogenous (species-specific) gene-specific sequence. The measurements are performed either by qPCR using an independent reference material as a calibrant or by dPCR [81-83].

A series of four key comparisons enabled NMIs and DIs to demonstrate and document their capabilities in measurements of the number of copies of specified intact sequence fragments extracted from different matrices and to determine their relative quantity. In the first two studies, matrices were rich in polymeric carbohydrate (amylose and amylopectin) and poor in fat: maize (Zea maize L.) seed powder in the CCQM-K86 study [84] and rice (Oryza sativa L.) seed powder in the CCQM-K86.b study [85]. In the third study, CCQM-K86.c, high-fat/oil matrix was selected, represented by rapeseed/canola (Brassica napus L.) seed powder [86]. Currently, a study on measuring DNA in high-protein matrix (meat) is in progress. All three studies on plant seed matrices had good agreement in the reported results, despite low relative quantities measured (ranging between 0.1 and $4 \%$ of GM content). While in the first study the majority of laboratories used the qPCR approach and calibrators for measurements, in the third study, all laboratories used the dPCR approach without calibrators.

These results confirmed consistency of measurements at NMIs and DIs worldwide, which resulted in the establishment of Calibration and Measurement Capabilities (CMCs) in $7 \mathrm{NMIs/DIs}$ at present (Table S2).

\section{Metrology for health}

While molecular testing is used in clinical diagnostics, reference methods are not as prevalent in this sector as they are in clinical chemistry; however, due to the desire of stakeholders to apply increasingly advanced high-throughput and quantitative measurements, this is changing and NAWG activities in the health sector are increasing. Currently, molecular diagnostic tools are used to genotype patients, to quantify pathogenic burden, to quantify transcriptional surrogate biomarkers of disease, or to measure disease predictors using subtle changes at the epigenetic level. To support NMI measurement capacity in these areas, a series of pilot studies focused on the identification and quantification of nucleic acid sequences were conducted (Table S3). In accordance with the BIPM guidelines measurement comparisons in CIPM MRA (CIPM MRA-G-11) [87], pilot studies are a third category of comparisons typically conducted to establish measurement parameters for a "new" field or instrument or as a training exercise.

To date, health-related NAWG pilot studies have mainly focused on the relative or absolute quantification of specific targets in simple matrices (aqueous buffer or cell suspension). The studies used a variety of sample types including pure synthetic and natural RNA and DNA, as well as whole cells.

The initial health studies aimed to investigate the capabilities to support measurements of mRNA biomarkers. Two studies were organized using exogenous synthetic targets from the External RNA Controls Consortium (ERCC) [33] as measurands. For the CCQM-P103 study, ERCC number 81 was selected as the measurand, while in the subsequent CCQM-P103.1 study, six ERCC standards were measured along with three endogenous gene transcripts present in the human cell line RNA background [88]. In the latter study, the majority of participants used RT-qPCR to measure the transcripts, while two participants used RT-dPCR and one used RNA-Seq. The results of these studies showed that the participating laboratories were able to measure target RNA quantities and fractional abundance (ratios) in a complex (total RNA) background with good concordance. In addition, the study highlighted the lack of a standardized approach for uncertainty calculations, especially when performing fractional abundance quantifications. Based on these results, a multiple cancer cell biomarker measurement pilot study (CCQM-P155) was organized, which used whole cell materials for analysis, to enable participant laboratories to develop and compare their nucleic acid extraction capabilities (Table S3). Another study dedicated to supporting the DNA-based diagnostics of cancer (CCQM-P184) is ongoing. The aim of this study is to measure the copy number concentrations of a single nucleotide variant (SNV) and small insertions and deletions (INDEL) present in a background of wild-type (wt) DNA (Table S3). To expand the measurement capabilities from small variants to large (structural) variants, a new study (CCQM-K176) on copy number variation of a breast cancer biomarker (HER2) is being conducted; this is the first key study in cancer diagnostics.

Following the progress in the field and to further explore the potential for using higher-accuracy SI-traceable methods for nucleic acid quantification, a study on absolute quantification of HIV-1 RNA copy number (CCQM-P199) was proposed followed by a similar study on SARS-CoV-2 copy 
number quantification (CCQM-P199.b) which was NAWG's response to the COVID-19 pandemic. Both studies demonstrated that NAWG members are capable of high-accuracy measurement of RNA molecules in buffered solutions. The CCQM-P199.b study demonstrated SARS-CoV-2 quantification was possible with most laboratories submitting values with $\pm 40 \%$ of the mean [45]. Reports of these studies are in preparation. These five RNA pilot studies open the possibility of future key comparisons, which are selected by the corresponding $\mathrm{CCs}$ to test the principal techniques and methods in the field [87].

In addition to studies organized by NAWG, NMIs and DIs are establishing their measurement capacities in support of different health areas within their regional metrology organizations. Within the aforementioned projects (Infect-Met, AntiMicroResist, BioSITrace, and SEPTIMET), reference measurement procedures for nucleic acid measurements were or are being developed. One of the aims of the BioSITrace project was to establish dPCR as a primary reference measurement procedure for DNA copy number quantification through comprehensive evaluation of sources of error and comparison with mass spectrometry measurements. A frequently occurring mutation in colorectal cancer (KRAS G12D) was used as a model, and the accuracy of dPCR for copy number quantification of point mutations was assessed by evaluating potential sources of uncertainty influencing measurements [89]. This work offered further evidence on the accuracy of dPCR measurements and supported its potential as a SI-traceable method. The measurement procedure developed within BioSITrace became the first reference measurement procedure for nucleic acids listed in the database of JCTLM [13]. Results of this project have contributed also to the revision of ISO 17511:2020 in vitro diagnostic medical devices - requirements for establishing metrological traceability of values assigned to calibrators, trueness control materials, and human samples [78].

Similarly in the frame of Infect-Met and AntiMicroResist projects, methods for reliable quantification of several infectious agents, human influenza A virus, human cytomegalovirus, Mycobacterium tuberculosis, and HIV, and their resistance were investigated [90-97]. One of the measurement procedures developed and evaluated in these projects, namely quantification of DNA extracted from human cytomegalovirus, has been also listed in the JCTLM database. This measurement procedure has been evaluated in External Quality Assessment schemes and showed the potential to harmonize for routine hCMV load testing [98]. The SEPTIMET project is currently developing quantitative methods and potential reference materials, as metrological support is needed for rapid near patient testing and innovative methods. In the response to the pandemic, part of the research within the SEPTIMET has been dedicated to SARS-CoV-2-related issues [99].
Besides the development of accurate measurement procedures, NMIs and DIs are developing controls and reference materials to support both local and international health sectors. For example, the National Institute of Standards and Technology (NIST) offers a range of reference materials for biometrology, including materials for cancer measurements [100-102], viral pathogens [103], microbial DNA (https://www-s.nist.gov/srmors/view_detail.cfm?srm= 8375), and human DNA [104, 105]. These materials cover a range of applications from relative abundance (SRM 2373) to absolute copy number (SRM 2365) to NGS (RM 8392). Similarly, the National Institute of Metrology, China (NIM China) has developed different DNA reference materials such as KRAS mutations in genomic DNA [106], BRAF V600E mutation, and different EGFR variants mimicking circulating tumor DNA [107, 108]. The Korea Research Institute of Standards and Science, South Korea (KRISS) has developed a representative DNA mixture in serum CRM for non-invasive prenatal testing (NIPT). This CRM is formulated to closely mimic the serum sample from a pregnant woman bearing a fetus with trisomy 21 , the most common chromosomal abnormality. In a pregnant woman's serum, a fraction of fetal DNA is present in addition to her own DNA, which are the target analytes in NIPT. The KRISS CRM for NIPT achieves its measurement traceability to the exact DNA amount mixed into the DNA-free serum matrix [109].

In response to the COVID-19 pandemic in 2020, a number of NMIs and DIs have developed SARS-CoV-2-related reference materials (RM), aiming to support nucleic acid testing [110]. Most of these RMs are in vitro transcribed RNA of SARS-CoV-2 genes [111]. The list of institutes offering materials made from in vitro transcripts of SARSCoV-2 includes NIM China [110]; NIST (USA) [110]; the National Measurement Institute (NMI Australia), Department of Industry, Science, Energy and Resources, Australian Government [112]; KRISS (South Korea) [110]; and TÜBİTAK UME (Turkey) [113]. Additionally, KRISS (South Korea), NIBSC, and NIM China have developed another form of RM, which is packaged SARS-CoV-2 RNA $[110,111,114]$. A few NMIs and DIs participated in the Collaborative Study for the Establishment of a WHO International Standard for SARS-CoV-2 RNA containing whole virus $[115,116]$. These materials have provided reliability in SARS-CoV-2 nucleic acid testing in local and international communities.

\section{Future perspectives}

As we progress into the next decade, NAWG activities will likely continue to support food-associated testing with key comparisons reflecting additional unmet needs, such as different matrices (e.g., protein rich), species (e.g., food 
adulterations), and molecular challenges (e.g., fragment size, strandedness, modifications like methylation). It is anticipated that food-associated measurements will expand to the agriculture/biotechnology sector; studies to support the monitoring of crop disease are planned which will expand the capacities of NAWG in view of the One Health approach. In line with its strategy heading for 2030 as well as the CCQM strategy document 2021-2030 [43], NAWG will considerably strengthen its activities associated with molecular reference measurement procedures (including structural and sequence purity) and reference materials to support clinical nucleic acid analysis. These activities are likely to build on established capabilities for underpinning SI-traceable quantitative measurements of nucleic acid copy number (per unit volume) in aqueous solutions $[89,91]$ and explore routes to apply such capacity to assist in matrix reference materials and/or reference measurements on real samples [90, 96, 117].

Developed capacities will also be of value to the other sectors such as industrial biotechnology where novel methods, such as CRISPR CAS-9-based genetic modification, are being applied [118, 119]. Biotechnology, especially the biopharmaceutical industry, performs numerous measurements to ensure the safety, quality, and efficiency of manufactured products [120]. Well-defined procedures for nucleic acid analysis are listed in almost all national and international pharmacopeias (e.g., IP, EP, USP, BP, JP, RSP, and others). NAWG member NMIs and DIs are establishing a solid base for measurements performed in industrial bioanalytical laboratories, by providing CRMs or reference measurement services to harmonize measurement results. As an example, measurement capabilities on the quantification of mycoplasmas, a common biotechnology manufacturing contaminant, will be investigated in an ongoing NAWG pilot study.

The increasing need for genomic, transcriptomic, and epigenomic analyses means that the NAWG will need to explore the development of strategies to support advanced sequencing capabilities, including for purity analysis. The metrological support in this area is lacking [120], and challenges associated with these types of "non-targeted" methods are likely to increase with the development of newer, simplified sequencing technologies more suitable to less specialized settings.

Last but not least, DNA measurements have become a valuable tool for environmental biodiversity monitoring. Sequencing of environmental DNA (DNA isolated from environmental samples) allows the identification of bacterial and eukaryotic species. Environmental DNA measurements, including quantitative DNA analysis, are used to study biodiversity and to monitor ecosystem changes. The NAWG strategy includes DNA (genomic and mitochondrial) sequencing-based species identification and bacterial quantification; participating NMIs/DIs will establish calibration and measurement capabilities in these areas in the near future.

\section{Conclusions}

As the use of nucleic acid analysis is increasingly applied across a wide range of sectors, measurement science will facilitate more a rapid and efficiency application. This will be needed to:

(1) Increase research accuracy and therefore our understanding of the biological systems we study

(2) Enable the translation of findings to routine application through preempting considerations that will ensure test applications are both robust and reproducible

(3) Facilitate routine application of nucleic acid analysis methods by enabling developers and users to demonstrate confidence in delivering the most accurate measurements

Along with associated relevant organizations, the CCQM NAWG and associated NMIs/DIs will continue to develop routes to ensure measurement accuracy and traceability for nucleic acid analysis. This will support measurement accuracy as molecular methods become increasingly applied for routine measurements to a wide variety of sectors.

Supplementary Information The online version contains supplementary material available at https://doi.org/10.1007/s00216-021-03712-x.

Acknowledgements The authors thank all NAWG members for their contributions in the development of metrology in nucleic acid measurement and the former chair of the NAWG, Helen Parkes (LGC), for her exemplary contribution to the working group.

Certain commercial equipment, instruments, and materials are identified to specify the experimental procedure. In no case does such identification imply recommendation or endorsement by the National Institute of Standards and Technology, National Measurement Laboratory (LGC), D.I. Mendeleev Institute for Metrology, Korea Research Institute of Standards and Science, and National Institute of Biology, nor does it imply that the materials or equipment are necessarily the best available for the purpose.

Author contributions M. Milavec had the idea for the article. M. Milavec, M.H. Cleveland, Y.-K. Bae, and M. Vonsky performed the literature search and drafted the work. R.I. Wielgosz and J.F. Huggett critically revised the work. All of the authors edited the manuscript.

Funding The work described in this paper was funded (in part) by the UK Government Department for Business, Energy \& Industrial Strategy (BEIS), in part by the Slovenian Research Agency (contract no. P4-0165), and in part by the National Research Council of Science and Technology given to KRISS (GP2020-0003/20011003), and internally funded by the NIST Bioscience Program.

Availability of data and material Not applicable. 
Code availability Not applicable.

\section{Declarations}

Ethics approval Not applicable.

Consent to participate Not applicable.

Consent for publication Not applicable.

Conflict of interest The authors declare no competing interests.

Open Access This article is licensed under a Creative Commons Attribution 4.0 International License, which permits use, sharing, adaptation, distribution and reproduction in any medium or format, as long as you give appropriate credit to the original author(s) and the source, provide a link to the Creative Commons licence, and indicate if changes were made. The images or other third party material in this article are included in the article's Creative Commons licence, unless indicated otherwise in a credit line to the material. If material is not included in the article's Creative Commons licence and your intended use is not permitted by statutory regulation or exceeds the permitted use, you will need to obtain permission directly from the copyright holder. To view a copy of this licence, visit http://creativecommons.org/licenses/by/4.0/.

\section{References}

1. Stark R, Grzelak M, Hadfield J. RNA sequencing: the teenage years. Nat Rev Genet. 2019;20:631-56. https://doi.org/10.1038/ s41576-019-0150-2.

2. Schadt EE, Turner S, Kasarskis A. A window into third-generation sequencing. Hum Mol Genet. 2010;19:227-40. https://doi. org $/ 10.1093 / \mathrm{hmg} / \mathrm{ddq} 416$.

3. Heather JM, Chain B. The sequence of sequencers: the history of sequencing DNA. Genomics. 2016;107:1-8. https://doi.org/ 10.1016/j.ygeno.2015.11.003.

4. Morley AA. Digital PCR: A brief history. Biomol Detect Quantif. 2014;1:1-2. https://doi.org/10.1016/j.bdq.2014.06.001.

5. European Union reference laboratory for genetically modified food and feed. https://gmo-crl.jrc.ec.europa.eu/. Accessed 20 Jun 2021

6. Tanaskovski B, Broothaerts W, Buttinger G, Corbisier P, Emteborg H, Robouch P, Emons H (2020) Determination of GM Maize MON88017 in bird feed and GM Maize GA21 in maize flour, EURL GMFF Proficiency Testing Report GMFF-20/01. JRC122118

7. Broothaerts W, Beaz Hidalgo R, Buttinger G, Corbisier P, Cordeiro F, Dimitrievska B, Emteborg H, Maretti M, Robouch P, Emons H (2019) Determination of GM Soybean 40-3-2 and MON87708 and GM Cotton GHB119 in animal feed and GM Soybean DAS- 44406 in soybean flour, EURL GMFF Proficiency Testing Report GMFF-19/02. JRC118375

8. Zeichhardt H, Donoso Mantke O. INSTAND Report External Quality Assessment Scheme Group 365 Virus Genome Detection - Cytomegalovirus September 2015. Düsseldorf: INSTAND e.V; 2015.

9. Zeichhardt H, Donoso Mantke O. INSTAND Report External Quality Assessment Scheme Group 365 Virus Genome Detection - Cytomegalovirus November/December 2014. Düsseldorf: INSTAND e.V; 2015.
10. International Organization for Standardization. https://www.iso. org/home.html. Accessed 20 Jun 2021

11. European Committee for Standardisation. https://www.cen.eu/ Pages/default.aspx. Accessed 20 Jun 2021

12. World Health Organisation. https://www.who.int/. Accessed 20 Jun 2021

13. The Joint Committee for Traceability in Laboratory Medicine (JCTLM). https://www.jctlm.org/. Accessed 20 Jun 2021

14. International Federation of Clinical Chemistry and Laboratory Medicine. https://www.ifcc.org/. Accessed 20 Jun 2021

15. Standardisation of Genome Amplification Techniques (SoGAT). https://www.nibsc.org/science_and_research/idd/idd_standards/ sogat.aspx. Accessed 20 Jun 2021

16. European Society of Clinical Microbiology and Infectious Diseases. https://www.escmid.org/. Accessed 20 Jun 2021

17. European Network of GMO Laboratories. https://gmo-crl.jrc. ec.europa.eu/ENGLabs. Accessed 20 Jun 2021

18. Codex Alimentarius International Food Standards. http://www. fao.org/fao-who-codexalimentarius/en/. Accessed 20 Jun 2021

19. International Plant Protection Convention. https://www.ippc. int/en/. Accessed 20 Jun 2021

20. European and Mediterranean Plant Protection Organization. https://www.eppo.int/. Accessed 20 Jun 2021

21. Asia Pacific Metrology Programme. http://www.apmpweb.org/ fms/general.php?tc_id=QM. Accessed 20 Jun 2021

22. Kaarls R (2018) The Consultative Committee for Metrology in Chemistry and Biology - CCQM. J Chem Metrol 12:1-16 . https://doi.org/10.25135/jcm.11.17.12.060

23. International Bureau of Weights and Measures. https://www. bipm.org/en/home. Accessed 20 Jun 2021

24. CCQM Working Group on Cell Analysis (CCQM-CAWG). https://www.bipm.org/en/committees/cc/ccqm/wg/ccqm-cawg. Accessed 20 Jun 2021

25. Consultative Committee for Amount of Substance: Metrology in Chemistry and Biology (CCQM). https://www.bipm.org/en/ committees/cc/ccqm/. Accessed 20 Jun 2021

26. General Conference on Weights and Measures (CGPM). https://www.bipm.org/en/committees/cg/cgpm. Accessed 20 Jun 2021

27. International Committee for Weights and Measures (CIPM). https://www.bipm.org/en/committees/cipm/. Accessed 20 Jun 2021

28. CIPM MRA documents. https://www.bipm.org/en/cipm-mra/ cipm-mra-documents. Accessed 20 Jun 2021

29. CIPM (2021) Calibration and measurement capabilities in the context of the CIPM MRA, Guidelines for their review, acceptance and maintenance, CIPM MRA-G-13. https://www.bipm. org/documents/20126/43742162/CIPM-MRA-G-13.pdf/f8b8c 429-42e0-4cf1-dc6c-bc60ab7f371a

30. Euro-Asian cooperation of National Metrological Institutions. https://www.coomet.net/. Accessed 20 Jun 2021

31. European Metrology Research Programme (EMRP). https://www. euramet.org/research-innovation/emrp/. Accessed 20 Jun 2021

32. European Metrology Programme for Innovation and Research (EMPIR). https://www.euramet.org/research-innovation/resea rch-empir/. Accessed 20 Jun 2021

33. Baker SC, Bauer SR, Beyer RP, Brenton JD, Bromley B, Burrill J, Causton H, Conley MP, Elespuru R, Fero M, Foy C, Fuscoe J, Gao X, Lee D, Gerhold GP, Goodsaid F, Guo X, Hackett J, Hockett RD, Ikonomi P, Irizarry RA, Kawasaki ES, KaysserKranich T, Kerr K, Kiser G, Koch WH, Lee KY, Liu C, Liu ZL, Lucas A, Manohar CF, Miyada G, Modrusan Z, Parkes H, Puri RK, Reid L, Ryder TB, Salit M, Samaha RR, Scherf U, Sendera TJ, Setterquist RA, Shi L, Shippy R, Soriano JV, Wagar EA, Warrington JA, Williams M, Wilmer F, Wilson M, Wolber 
PK, Wu X, Zadro R. The External RNA Controls Consortium: a progress report. Nat Methods. 2005;2:731-4. https://doi.org/10. 1038/nmeth1005-731.

34. EURAMET - The European Association of National Metrology Institutes. https://www.euramet.org/. Accessed 20 Jun 2021

35. BIPM key comparison database. https://www.bipm.org/kcdb/. Accessed 20 Jun 2021

36. MWG 8- CHEMISTRY. https://sim-metrologia.org/about-us/ structure/technical-committee/chemistry/. Accessed 20 Jun 2021

37. CCQM Working Group on Nucleic Acid Analysis (CCQMNAWG). https://www.bipm.org/en/committees/cc/ccqm/wg/ ccqm-nawg. Accessed 20 Jun 2021

38. CCQM Working Group on Protein Analysis (CCQM-PAWG). https://www.bipm.org/en/committees/cc/ccqm/wg/ccqm-pawg. Accessed 20 Jun 2021

39. The International System of Units (SI). https://www.bipm.org/ en/measurement-units. Accessed 20 Jun 2021

40. Joint Committee for Guides in Metrology (2012) JCGM 200:2012 International vocabulary of metrology - Basic and general concepts and associated terms (VIM) 3rd edition. 104

41. Inter-American Metrology System (SIM). https://sim-metrologia. org/. Accessed 20 Jun 2021

42. Technical Committee of Metrology in Chemistry (TC-MC). https://www.euramet.org/technical-committees/tc-mc/. Accessed 20 Jun 2021

43. Consultative Committee for Amount of Substance: Metrology in Chemistry Biology (2021) CCQM strategy document 20212030. Version 1.0. https://www.bipm.org/documents/20126/ 41532413/CCQM+Strategy/31283069

44. Camloh M, Dreo T, Gruden K, Mehle N, Milavec M, Zel J (2015) Nucleic-acid analysis in new fields of metrology. 17th Int Congr Metrol CIM 2015 5:1-5 . https://doi.org/10.1051/metrology/ 20150006005

45. National Measurement Institutes demonstrate high accuracy reference measurement system for SARS-CoV-2 testing. https:// www.bipm.org/en//-/2020-nmi-covid. Accessed 20 Jun 2021

46. Euro-Asian cooperation of National Metrological Institutions TC 1.8 "'Physical Chremistry." https://www.coomet.net/organizati on/tc-18-physical-chemistry/. Accessed 20 Jun 2021

47. Metrology for monitoring infectious diseases, antimicrobial resistance, and harmful micro-organisms. https://www.euramet. org/research-innovation/search-research-projects/details/project/ metrology-for-monitoring-infectious-diseases-antimicrobial-resis tance-and-harmful-micro-organisms/. Accessed 20 Jun 2021

48. Novel materials and methods for the detection, traceable monitoring and evaluation of antimicrobial resistance. https://www. euramet.org/research-innovation/search-research-projects/detai 1s/project/novel-materials-and-methods-for-the-detection-trace able-monitoring-and-evaluation-of-antimicrobial/. Accessed 20 Jun 2021

49. Traceability for biologically relevant molecules and entities. https://www.euramet.org/research-innovation/search-researchprojects/details/project/traceability-for-biologically-relevantmolecules-and-entities/. Accessed 20 Jun 2021

50. Metrology to enable rapid and accurate clinical measurements in acute management of sepsis. https://www.euramet.org/resea rch-innovation/search-research-projects/details/project/metro logy-to-enable-rapid-and-accurate-clinical-measurements-inacute-management-of-sepsis/. Accessed 20 Jun 2021

51. EMN for Traceability in Laboratory Medicine. https://www. euramet.org/european-metrology-networks/laboratory-medic ine/. Accessed 20 Jun 2021

52. Commission E. Regulation (EU) 2017/746 of the European parliament and of the council on in vitro diagnostic medical devices. Off J Eur Union. 2017;117:176-332.
53. Commission E. REGULATION (EU) 2017/745 OF THE EUROPEAN PARLIAMENT AND OF THE COUNCIL of 5 April 2017 on medical devices, amending Directive 2001/83/EC, Regulation (EC) No 178/2002 and Regulation (EC) No 1223/2009 and repealing Council Directives 90/385/EEC and 93/42/EE. Off J Eur Union. 2017;117:1-175.

54. Baoutina A, Bhat S, Partis L, Emslie KR. Storage Stability of Solutions of DNA Standards. Anal Chem. 2019;91:12268-74. https://doi.org/10.1021/acs.analchem.9b02334.

55. Lee SB, Crouse CA, Kline MC. Optimizing Storage and Handling of DNA Extracts. Forensic Sci Rev. 2010;22:131-44.

56. Nordin G, Dybkaer R, Forsum U, Fuentes-Arderiu X, Pontet F. Vocabulary on nominal property, examination, and related concepts for clinical laboratory sciences (IFCC-IUPAC Recommendations 2017). Pure Appl Chem. 2018;90:913-35. https://doi.org/ 10.1515/pac-2011-0613.

57. International Nucleotide Sequence Database Collaboration (INSDC). http://www.insdc.org/. Accessed 20 Jun 2021

58. GenBank. www.ncbi.nlm.nih.gov/genbank. Accessed 20 Jun 2021

59. European Nucleotide Archive ENA. www.ebi.ac.uk/ena. Accessed 20 Jun 2021

60. DNA Databank of Japan. www.ddbj.nig.ac.jp. Accessed 20 Jun 2021

61. RefSeq. ncbi.nlm.nih.gov/refseq. Accessed 20 Jun 2021

62. Bogožalec Košir A, Divieto C, Pavšič J, Pavarelli S, Dobnik D, Dreo T, Bellotti R, Sassi MP, Žel J. Droplet volume variability as a critical factor for accuracy of absolute quantification using droplet digital PCR. Anal Bioanal Chem. 2017;409:6689-97. https://doi.org/10.1007/s00216-017-0625-y.

63. Dagata J a., Farkas N, Kramer J a. (2016) Method for measuring the volume of nominally $100 \mu \mathrm{m}$ diameter spherical water-in-oil emulsion droplets. Special Publication (NIST SP). National Institute of Standards and Technology, Gaithersburg, MD, [online], https://doi.org/10.6028/NIST.SP.260-184 Accessed June 20, 2021

64. Pinheiro LB, Coleman VA, Hindson CM, Herrmann J, Hindson BJ, Bhat S, Emslie KR. Evaluation of a droplet digital polymerase chain reaction format for DNA copy number quantification. Anal Chem. 2012;84:1003-11. https://doi.org/10.1021/ac202 $578 x$.

65. Corbisier P, Pinheiro L, Mazoua S, Kortekaas A-M, Chung PYJ, Gerganova T, Roebben G, Emons H, Emslie K. DNA copy number concentration measured by digital and droplet digital quantitative PCR using certified reference materials. Anal Bioanal Chem. 2015;407:1831-40. https://doi.org/10.1007/ s00216-015-8458-z.

66. Yoo H-B, Park S-R, Dong L, Wang J, Sui Z, Pavšič J, Milavec M, Akgoz M, Mozioğlu E, Corbisier P, Janka M, Cosme B, de V. Cavalcante JJ, Flatshart RB, Burke D, Forbes-Smith M, McLaughlin J, Emslie K, Whale AS, Huggett JF, Parkes H, Kline MC, Harenza JL, Vallone PM, . International comparison of enumeration-based quantification of DNA copy-concentration using flow cytometric counting and digital polymerase chain reaction. Anal Chem. 2016;88:12169-76. https://doi.org/10.1021/acs. analchem.6b03076.

67. Huggett JF, Foy CA, Benes V, Emslie K, Garson JA, Haynes R, Hellemans J, Kubista M, Mueller RD, Nolan T, Pfaffl MW, Shipley GL, Vandesompele J, Wittwer CT, Bustin SA. The digital MIQE guidelines: minimum information for publication of quantitative digital PCR experiments. Clin Chem. 2013;59:892-902. https://doi.org/10.1373/clinchem.2013.206375.

68. Huggett JF, Whale AS, De Spiegelaere W, Trypsteen W, Nour AA, Bae Y-K, Benes V, Burke D, Cleveland M, Corbisier P, Devonshire AS, Dong L, Drandi D, Foy CA, Garson JA, He H-J, Hellemans J, Kubista M, Lievens A, Makrigiorgos MG, 
Milavec M, Mueller RD, Nolan T, O’Sullivan DM, Pfaffl MW, Rödiger S, Romsos EL, Shipley GL, Taly V, Untergasser A, Wittwer CT, Bustin SA, Vandesompele J, Huggett JF. The digital MIQE guidelines update: minimum information for publication of quantitative digital PCR experiments for 2020. Clin Chem. 2020;66:1012-29. https://doi.org/10.1093/clinchem/hvaa125.

69. Bustin SA, Benes V, Garson JA, Hellemans J, Huggett J, Kubista M, Mueller R, Nolan T, Pfaffl MW, Shipley GL, Vandesompele J, Wittwer CT. The MIQE guidelines: minimum information for publication of quantitative real-time PCR experiments. Clin Chem. 2009;55:611-22. https://doi.org/10.1373/clinchem.2008. 112797.

70. Bharucha T, Oeser C, Balloux F, Brown JR, Carbo EC, Charlett A, Chiu CY, Claas ECJ, de Goffau MC, de Vries JJC, Eloit M, Hopkins S, Huggett JF, MacCannell D, Morfopoulou S, Nath A, O'Sullivan DM, Reoma LB, Shaw LP, Sidorov I, Simner PJ, Van Tan L, Thomson EC, van Dorp L, Wilson MR, Breuer J, Field N. STROBE-metagenomics: a STROBE extension statement to guide the reporting of metagenomics studies. Lancet Infect Dis. 2020;20:e251-60. https://doi.org/10.1016/S1473-3099(20) 30199-7.

71. Minimum information for biological and biomedical investigations. https://fairsharing.org/collection/MIBBI. Accessed 20 Jun 2021

72. Burns M, Wiseman G, Knight A, Bramley P, Foster L, Rollinson S, Damant A, Primrose S. Measurement issues associated with quantitative molecular biology analysis of complex food matrices for the detection of food fraud. Analyst. 2016;141:45-61. https:// doi.org/10.1039/C5AN01392E.

73. Pecoraro S, Berben G, Burns M, Corbisier P, De Giacomo M, De Loose M, Dagand E, Dobnik D, Eriksson R, Holst-Jensen A, Kagkli D-M, Kreysa J, Lievens A, Mäde D, Mazzara M, Paternò A, Peterseil V, Savini C, Sovová T, Sowa S, Spilsberg B (2019) Overview and recommendations for the application of digital PCR. EUR 29673 EN, Publications Office of the European Union, Luxembourg, 2019, ISBN 978-92-76- 00180-5, doi:https://doi.org/10.2760/192883, JRC 115736.

74. Trapman S, Burns M, Corbisier P, Gatto F, Robouch P, Sowa S, Emons H (2020) Guidance document on measurement uncertainty for GMO testing laboratories, 3rd ed. EUR 30248 EN, Publications Office of the European Union, Luxembourg, ISBN 978-92-76-19432-3, doi:https://doi.org/10.2760/738565, JRC120898

75. Burns M, Foster L, Walker M. DNA techniques to verify food authenticity. The Royal Society of Chemistry; 2020.

76. International Organization for Standardization (2019) ISO 20395:2019 biotechnology — requirements for evaluating the performance of quantification methods for nucleic acid target sequences - qPCR and dPCR

77. International Organization for Standardization (2020) ISO 17822:2020 In vitro diagnostic test systems - nucleic acid amplification-based examination procedures for detection and identification of microbial pathogens - Laboratory quality practice guide

78. International Organization for Standardization (2020) ISO 17511:2020 In vitro diagnostic medical devices — requirements for establishing metrological traceability of values assigned to calibrators, trueness control materials and human samples

79. Žel J, Milavec M, Morisset D, Plan D, Van den Eede G, Gruden K. How to reliably test for GMOs. US, Boston, MA: Springer; 2012.

80. Milavec M, Dobnik D, Yang L, Zhang D, Gruden K, Žel J. GMO quantification: Valuable experience and insights for the future. Anal Bioanal Chem. 2014;406:6485-97.

81. Corbisier P, Bhat S, Partis L, Rui Dan Xie V, Emslie KR. Absolute quantification of genetically modified MON810 maize
(Zea mays L.) by digital polymerase chain reaction. Anal Bioanal Chem. 2010;396:2143-50. https://doi.org/10.1007/ s00216-009-3200-3.

82. Morisset D, Stebih D, Milavec M, Gruden K, Žel J. Quantitative analysis of food and feed samples with droplet digital PCR. PLoS ONE. 2013;8: e62583. https://doi.org/10.1371/journal. pone.0062583.

83. Bogožalec Košir A, Demšar T, Štebih D, Žel J, Milavec M. Digital PCR as an effective tool for GMO quantification in complex matrices. Food Chem. 2019;294:73-8. https://doi.org/10.1016/j. foodchem.2019.05.029.

84. Corbisier P, Vincent S, Schimmel H, Kortekaas A-M, Trapmann S, Burns M, Bushell C, Akgoz M, Akyürek S, Dong L, Fu B, Zhang L, Wang J, Pérez Urquiza M, Bautista JL, Garibay A, Fuller B, Baoutina A, Partis L, Emslie K, Holden M, Chum WY, Kim H-H, Phunbua N, Milavec M, Zel J, Vonsky M, Konopelko LA, Lau TLT, Yang B, Hui MHK, Yu ACH, Viroonudomphol D, Prawettongsopon C, Wiangnon K, Takabatake R, Kitta K, Kawaharasaki M, Parkes H. CCQM-K86/P113.1: Relative quantification of genomic DNA fragments extracted from a biological tissue. Metrologia. 2012;49:08002-08002. https://doi.org/10. 1088/0026-1394/49/1A/08002.

85. Dong L, Sui Z, Wang J, Tang VHM, Chum WWY, Lee F, Sin DWM, Pérez-Urquiza M, Burns M, Ellison SLR, Parkes H, Milavec M, Prawettongsopon C, Griffiths KR, McLaughlin JLH, Shibayama S, Akyurek S, Akgoz M (2018) Final report for CCQM-K86.b relative quantification of Bt63 in GM rice matrix sample. Metrologia 55:8017 . https://doi.org/10.1088/0026-1394/ 55/1a/08017

86. Mester Z, Corbisier P, Ellison SLR, Gao Y, Niu C, Tang V, Lee F, Pérez-Urquiza M, Suárez AR, Burns M, Milavec M, Wiangnon K, Griffiths KR, McLaughlin JLH, Shibayama S, Takatsu A, Akgoz M, Vonsky M, Runov A, Guerrero JEL. Final report of CCQM-K86.c. Relative quantification of genomic DNA fragments extracted from a biological tissue. Metrologia. 2020;57:08004-08004. https://doi.org/10.1088/0026-1394/57/ $1 \mathrm{~A} / 08004$.

87. CIPM (2021) Measurement comparisons in the CIPM MRA, guidelines for organizing, participating and reporting, CIPM MRA-G-11, https://www.bipm.org/documents/20126/43742162/ CIPM-MRA-G-11.pdf/9fe6fb9a-500c-9995-2911-342f8126226c

88. Devonshire AS, Sanders R, Whale AS, Nixon GJ, Cowen S, Ellison SLR, Parkes H, Pine S, Salit M, McDaniel J, Munro S, Lund S, Matsukura S, Sekiguchi Y, Kawaharasaki M, Granjeiro JM, Falagan-Lotsch P, Saraiva AM, Couto P, Yang I, Kwon H, Park SR, Demšar T, Žel J, Blejec A, Milavec M, Dong L, Zhang L, Sui Z, Wang J, Viroonudomphol D, Prawettongsopon C, Partis L, Baoutina A, Emslie K, Takatsu A, Akyurek S, Akgoz M, Vonsky M, Konopelko L, Cundapi EM, Urquiza MP, Huggett JF, Foy CA. An international comparability study on quantification of mRNA gene expression ratios: CCQM-P103.1. Biomol Detect Quantif. 2016;8:15-28. https://doi.org/10.1016/j.bdq.2016.05. 003.

89. Whale AS, Jones GM, Pavšič J, Dreo T, Redshaw N, Akyürek S, Akgöz M, Divieto C, Sassi MP, He HJ, Cole KD, Bae YK, Park SR, Deprez L, Corbisier P, Garrigou S, Taly V, Larios R, Cowen S, O'Sullivan DM, Bushell CA, Goenaga-Infante H, Foy CA, Woolford AJ, Parkes H, Huggett JF, Devonshire AS. Assessment of digital PCR as a primary reference measurement procedure to support advances in precision medicine. Clin Chem. 2018;64:1296-307. https://doi.org/10.1373/clinchem.2017. 285478.

90. Whale AS, Bushell CA, Grant PR, Cowen S, Gutierrez-Aguirre I, O’Sullivan DM, Žel J, Milavec M, Foy CA, Nastouli E, Garson JA, Huggett JF. Detection of rare drug resistance mutations by digital PCR in a human influenza a virus model system and 
clinical samples. J Clin Microbiol. 2016;54:392-400. https://doi. org/10.1128/JCM.02611-15.

91. Pavšič J, Devonshire A, Blejec A, Foy CA, Van Heuverswyn F, Jones GM, Schimmel H, Žel J, Huggett JF, Redshaw N, Karczmarczyk M, Mozioğlu E, Akyürek S, Akgöz M, Milavec M. Inter-laboratory assessment of different digital PCR platforms for quantification of human cytomegalovirus DNA. Anal Bioanal Chem. 2017;409:2601-14. https://doi.org/10.1007/ s00216-017-0206-0.

92. Pavšič J, Žel J, Milavec M. Digital PCR for direct quantification of viruses without DNA extraction. Anal Bioanal Chem. 2016;408:67-75. https://doi.org/10.1007/s00216-015-9109-0.

93. Pavšič J, Žel J, Milavec M. Assessment of the real-time PCR and different digital PCR platforms for DNA quantification. Anal Bioanal Chem. 2016;408:107-21. https://doi.org/10.1007/ s00216-015-9107-2.

94. Bogožalec Košir A, Cvelbar T, Kammel M, Grunert HP, Zeichhardt H, Milavec M. Digital PCR method for detection and quantification of specific antimicrobial drug-resistance mutations in human cytomegalovirus. J Virol Methods. 2020;281: 113864. https://doi.org/10.1016/j.jviromet.2020.113864.

95. Devonshire AS, Honeyborne I, Gutteridge A, Whale AS, Nixon G, Wilson P, Jones G, McHugh TD, Foy CA, Huggett JF. Highly reproducible absolute quantification of Mycobacterium tuberculosis complex by digital PCR. Anal Chem. 2015;87:3706-13. https://doi.org/10.1021/ac5041617.

96. Devonshire AS, O'Sullivan DM, Honeyborne I, Jones G, Karczmarczyk M, Pavšič J, Gutteridge A, Milavec M, Mendoza P, Schimmel H, Van Heuverswyn F, Gorton R, Cirillo DM, Borroni E, Harris K, Barnard M, Heydenrych A, Ndusilo N, Wallis CL, Pillay K, Barry T, Reddington K, Richter E, Mozioğlu E, Akyürek S, Yalçınkaya B, Akgoz M, Žel J, Foy CA, McHugh TD, Huggett JF. The use of digital PCR to improve the application of quantitative molecular diagnostic methods for tuberculosis. BMC Infect Dis. 2016;16:366. https://doi.org/10.1186/ s12879-016-1696-7.

97. Falak S, Macdonald R, Busby EJ, O’Sullivan DM, Milavec M, Plauth A, Kammel M, Zeichhardt H, Grunert HP, Kummrow A, Huggett JF. An assessment of the reproducibility of reverse transcription digital PCR quantification of HIV-1. Methods. 2021. https://doi.org/10.1016/j.ymeth.2021.03.006.

98. Milavec M, Pavšič J, Bogožalec Košir A, Jones GM, O'Sullivan DM, Devonshire AS, Van Heuverswyn F, Karczmarczyk M, Neeb J, Plauth A, Corbisier P, Schimmel H, Kummrow A, Neukammer J, Foy CA, Kammel M, Grunert HP, Zeichhardt H, Huggett JF. The performance of human cytomegalovirus digital PCR reference measurement procedure in seven external quality assessment schemes over four years. Methods. 2021. https://doi. org/10.1016/j.ymeth.2021.03.016.

99. Huggett JF, Benes V, Bustin SA, Garson JA, Harris K, Kammel M, Kubista M, McHugh TD, Moran-Gilad J, Nolan T, Pfaffl MW, Salit M, Shipley G, Vallone PM, Vandesompele J, Wittwer C, Zeichhardt H. Cautionary note on contamination of reagents used for molecular detection of SARS-CoV-2. Clin Chem. 2020;66:1369-72. https://doi.org/10.1093/clinchem/hvaa214.

100. He H-J, Almeida JL, Lund SP, Steffen CR, Choquette S, Cole KD. Development of NIST standard reference material 2373: Genomic DNA standards for HER2 measurements. Biomol Detect Quantif. 2016;8:1-8. https://doi.org/10.1016/j.bdq.2016. 02.001 .

101. Lih C-J, Si H, Das B, Harrington RD, Harper KN, Sims DJ, McGregor PM, Camalier CE, Kayserian AY, Williams PM, He H-J, Almeida JL, Lund SP, Choquette S, Cole KD. Certified DNA reference materials to compare HER2 gene amplification measurements using next-generation sequencing methods. J Mol
Diagnostics. 2016;18:753-61. https://doi.org/10.1016/j.jmoldx. 2016.05.008.

102. He H-J, Das B, Cleveland MH, Chen L, Camalier CE, Liu L-C, Norman KL, Fellowes AP, McEvoy CR, Lund SP, Almeida J, Steffen CR, Karlovich C, Williams PM, Cole KD. Development and interlaboratory evaluation of a NIST Reference Material RM 8366 for EGFR and MET gene copy number measurements. Clin Chem Lab Med. 2019;57:1142-52. https://doi.org/10.1515/ cclm-2018-1306.

103. Cleveland MH, Farkas N, Kiesler KM, Toman B, Vallone PM (2018) Certification of standard reference material 2365 BK virus DNA quantitative standard. Special Publication (NIST SP), National Institute of Standards and Technology. Gaithersburg, MD, [online], https://doi.org/10.6028/NIST.SP.260-191

104. Romsos EL, Kline MC, Duewer DL, Toman B, Farkas N (2018) Certification of standard reference material 2372a human DNA quantitation standard. Special Publication (NIST SP), National Institute of Standards and Technology. Gaithersburg, MD, [online], https://doi.org/10.6028/NIST.SP.260-189

105. Zook JM, Hansen NF, Olson ND, Chapman L, Mullikin JC, Xiao C, Sherry S, Koren S, Phillippy AM, Boutros PC, Sahraeian SME, Huang V, Rouette A, Alexander N, Mason CE, Hajirasouliha I, Ricketts C, Lee J, Tearle R, Fiddes IT, Barrio AM, Wala J, Carroll A, Ghaffari N, Rodriguez OL, Bashir A, Jackman S, Farrell JJ, Wenger AM, Alkan C, Soylev A, Schatz MC, Garg S, Church G, Marschall T, Chen K, Fan X, English AC, Rosenfeld JA, Zhou W, Mills RE, Sage JM, Davis JR, Kaiser MD, Oliver JS, Catalano AP, Chaisson MJP, Spies N, Sedlazeck FJ, Salit M. A robust benchmark for detection of germline large deletions and insertions. Nat Biotechnol. 2020;38:1347-55. https:// doi.org/10.1038/s41587-020-0538-8.

106. Dong L, Wang S, Fu B, Wang J. Evaluation of droplet digital PCR and next generation sequencing for characterizing DNA reference material for KRAS mutation detection. Sci Rep. 2018;8:9650. https://doi.org/10.1038/s41598-018-27368-3.

107. Wang X, Zhang Y, Niu C, Wang S, Li L, Guo Y, Zhu L, Jin X, Gao H, Xu W, Zhu P, Lan Q, Du M, Cheng X, Gao Y, Dong L. Establishment of primary reference measurement procedures and reference materials for EGFR variant detection in non-small cell lung cancer. Anal Methods. 2021;13:2114-23. https://doi.org/10. 1039/D1AY00328C.

108. Dong L, Wang X, Wang S, Du M, Niu C, Yang J, Li L, Zhang G, Fu B, Gao Y, Wang J. Interlaboratory assessment of droplet digital PCR for quantification of BRAF V600E mutation using a novel DNA reference material. Talanta. 2020;207: 120293. https://doi.org/10.1016/j.talanta.2019.120293.

109. Kwon H-J, Jeong J-S, Bae Y-K, Choi K, Yang I. Stable isotope labeled DNA: a new strategy for the quantification of total DNA using liquid chromatography-mass spectrometry. Anal Chem. 2019;91:3936-43. https://doi.org/10.1021/acs.analchem.8b049 40.

110. Metrology in the fight against Covid-19 - Contributions from NMIs. https://www.bipm.org/en/metrology-in-the-fight-again st-covid-19/nmi-contributions

111. Yoo HM, Kim I-H, Kim S. Nucleic acid testing of SARS-CoV-2. Int J Mol Sci. 2021;22:6150. https://doi.org/10.3390/ijms221161 50.

112. National Measurement Institute Australia (2021) Certified Reference Material Certificate of Analysis NMIA NA050 to NA055: SARS-CoV-2 standard. Australian Government, Department of industry, Science, Energy and Resources, https://www.industry. gov.au/sites/default/files/2020-12/sars-cov-2_c_of_a_b200921_ feb_2021.pdf

113. Akyurek S, Demirci SNS, Bayrak Z, Isleyen A, Akgoz M. The production and characterization of SARS-CoV-2 RNA reference 
material. Anal Bioanal Chem. 2021;413:3411-9. https://doi.org/ 10.1007/s00216-021-03284-w.

114. NIBSC. Working standard, working reagent for SARS-CoV-2 RNA. NIBSC code. 2021;20(138):1-2.

115. Jorajuria S, Fernandes M, Vees M, Dujardin V, Regourd E. Collaborative study for the establishment of the 3rd international standard for amphotericin B. Pharmeur Bio Sci Notes. 2020;2020:25-48.

116. WHO (2021) WHO International Standard First WHO International Standard for SARS-CoV-2 RNA NIBSC code: 20/146. 1-2

117. Ahmad-Nejad P, Ashavaid T, Vacaflores Salinas A, Huggett J, Harris K, Linder MW, Baluchova K, Steimer W, Payne DA. Current and future challenges in quality assurance in molecular diagnostics. Clin Chim Acta. 2021;519:239-46. https://doi.org/ 10.1016/j.cca.2021.05.004.

118. Karimian A, Azizian K, Parsian H, Rafieian S, Shafiei-Irannejad V, Kheyrollah M, Yousefi M, Majidinia M, Yousefi B. CRISPR/ Cas9 technology as a potent molecular tool for gene therapy. J
Cell Physiol. 2019;234:12267-77. https://doi.org/10.1002/jcp. 27972.

119. Doudna JA, Charpentier E (2014) The new frontier of genome engineering with CRISPR-Cas9. Science (80- ) 346:1258096. https://doi.org/10.1126/science.1258096

120. O'Sullivan DM, Doyle RM, Temisak S, Redshaw N, Whale AS, Logan G, Huang J, Fischer N, Amos GCA, Preston MD, Marchesi JR, Wagner J, Parkhill J, Motro Y, Denise H, Finn RD, Harris KA, Kay GL, O'Grady J, Ransom-Jones E, Wu H, Laing E, Studholme DJ, Benavente ED, Phelan J, Clark TG, MoranGilad J, Huggett JF. An inter-laboratory study to investigate the impact of the bioinformatics component on microbiome analysis using mock communities. Sci Rep. 2021;11:10590. https://doi. org/10.1038/s41598-021-89881-2.

Publisher's note Springer Nature remains neutral with regard to jurisdictional claims in published maps and institutional affiliations. 